\title{
Blood antioxidant enzymes as markers of exposure or effect in coal miners
}

\author{
Rachel Perrin-Nadif, Guy Auburtin, Martine Dusch, Jean-Marc Porcher, Jean-Marie Mur
}

\begin{abstract}
Objective-To investigate if blood $\mathrm{Cu}^{++} / \mathbf{Z n}^{++}$superoxide dismutase, glutathione peroxidase, catalase, and total plasma antioxidant activities could be markers of biological activity resulting from exposure to respirable coal mine dust in active miners, and of pneumoconiosis in retired miners.

Methods-Blood samples were randomly obtained from active surface workers $(\mathbf{n}=30)$ and underground miners $(\mathbf{n}=$ 34), and from retired miners without $(n=$ $21)$, and with $(n=33)$ pneumoconiosis. Antioxidant enzyme activities and total plasma antioxidants were measured in erythrocytes and plasma. Non-parametric tests were completed by analyses of covariance to compare antioxidants between groups, taking into account potential confounding factors (age, smoking history (pack-years)).
\end{abstract}

Results-Erythrocyte $\mathbf{C u}^{++} / \mathbf{Z n}^{++}$superoxide dismutase activity was significantly higher in the group of underground miners than the group of surface workers. The differences in total plasma antioxidants and plasma glutathione peroxidase activity between both groups were related to age. Glutathione peroxidase activity increased in the plasma of retired miners with pneumoconiosis, compared with retired miners without pneumoconiosis. No differences were found either in erythrocyte antioxidant enzyme activities or in total plasma antioxidants between the groups of retired miners without and with pneumoconiosis.

Conclusions-In this study, erythrocyte $\mathrm{Cu}^{++} / \mathbf{Z n}^{++}$superoxide dismutase activity may be considered as a marker of effect of respirable coal mine dust in exposed workers. This result is in agreement with the hypothesis that reactive oxygen species are involved in cell injury induced by coal mine dust, and may be predictive of the degree of inflammation and pneumoconiosis induced by coal mine dust. The increase in glutathione peroxidase activity in the plasma of retired miners with pneumoconiosis may be the result of a response to the increasing hydrogen peroxide $\left(\mathrm{H}_{2} \mathrm{O}_{2}\right)$ production due to the disease process.

(Occup Environ Med 1996;53:41-45)

Keywords: antioxidant enzymes; coal workers' pneumoconiosis; reactive oxygen species
Chronic exposure to (coal mine) dust particles induces an influx of inflammatory cells in the lung. The phagocytosis of inhaled particles is followed by the activation of macrophages and leucocytes, thus releasing proteases, inflammatory mediators, and reactive oxygen species. ${ }^{1}$ Superoxide anion $\left(\mathrm{O}_{2^{-}}{ }^{-}\right)$is liberated on the cell surface of activated phagocytes by a NADPH dependent oxidase in the cell membrane. ${ }^{2} \mathrm{~A}$ significant part of $\mathrm{O}_{2}{ }^{-}$is released into the extracellular space, ${ }^{3}$ and is spontaneously converted into hydrogen peroxide $\left(\mathrm{H}_{2} \mathrm{O}_{2}\right)$. Moreover, dust particles themselves may generate reactive oxygen species. ${ }^{45}$ This continuous activation results in an imbalance between oxidant and anti-oxidant agents, proteases and antiproteases, as well as between the various cytokines and growth factors. This leads to abnormal remodelling and architecture of components of the extracellular matrix.

As a response to these potentially direct actions of reactive oxygen species, the human body possesses antioxidant mechanisms; they include enzymes that have antioxidant activity and many actual and putative physiological antioxidants (such as $\alpha$ tocopherol). The main enzymes that provide cellular protection against damage due to reactive oxygen species in human cells are three superoxide dismutases (SODs), catalase, and a selenoenzyme glutathione peroxidase. The SODs include two $\mathrm{Cu}^{++} / \mathrm{Zn}^{++}$SODs, one occurs extracellularly and the other within peroxisomes in the cytoplasm. The third form contains manganese (MnSOD), occurs almost exclusively in the mitochondria, and responds quickly to oxidant stress. ${ }^{6}$ The SODs convert $\mathrm{O}_{2} .^{-}$to $\mathrm{H}_{2} \mathrm{O}_{2}$, and catalase and glutathione peroxidase convert $\mathrm{H}_{2} \mathrm{O}_{2}$ to oxygen and water. As reactive oxygen species have very short half lives, ${ }^{7}$ the measurements of these enzyme activities in blood is a non-invasive test that could be used to investigate the effects of chronic occupational exposure to oxidants in humans.

Coal workers' pneumoconiosis (CWP) is an occupational disease that manifests itself usually after several decades of exposure to coal mine dusts. Between exposure in the ambient environment and the development of clinical disease, four generically different classes of biological markers have been identified. ${ }^{8} \mathrm{~A}$ marker of early biological effect is an event, correlated with, and possibly predictive of, health impairment. A definition of biological markers was put forward by Schulte ${ }^{8}$ from the National Institute of Occupational Safety and Health (NIOSH) as "biologic markers may represent signals in a continuum of events 
between a causal exposure and resultant disease". This study is part of a larger project on the measurement of lipoperoxydation in the respiratory inflammation processes in coal miners. The purpose of this study is to investigate if blood $\mathrm{Cu}^{++} / \mathrm{Zn}^{++} \mathrm{SOD}$, glutathione peroxidase, catalase, and total plasma antioxidant activities can be markers of either biological activity resulting from exposure to coal mine dust, or of pneumoconiosis in coal miners.

\section{Materials and methods}

STUDY SAMPLE

The study is composed of four groups of workers in a French coal mine "Houillères du Bassin de Lorraine" (Forbach, Moselle): one group consists of underground miners, one control group consists of surface workers, one group consists of retired coal miners without CWP, and one group consists of retired coal miners with CWP.

Underground coal miners were randomly sampled among current coal face miners, born between January 1948 and December 1958. Surface workers, selected as a control group, were randomly sampled from pit head workers, in the same age range. The absence of usual exposure to dust or respiratory irritants was a selection criterion, based on job title and checked by the occupational physician. In both groups the selection criteria included the absence of pneumoconiosis and lung function abnormalities (forced expiratory volume in one second/forced vital capacity $\left(\mathrm{FEV}_{1} / \mathrm{FVC}\right)$ $<70 \%$ or $\mathrm{FEV}_{1}$ or FVC outside predicted European standard values)..$^{9}$

Retired coal miners were selected by systematic sampling among patients attending the occupational lung disease centre (CEPPR) for periodic surveillance of patients compensated for pneumoconiosis or for the CWP screening programme. They had to be born between January 1918 and December 1938. Subjects with lung function abnormalities were excluded to improve alveolar space sampling of exhaled air for the measurement of alkanes as markers of lipidoperoxidation, another part of the project.

The size of each group $(n=30)$ was decided for a larger project on the measurement of biomarkers of lipidoperoxidation in the respiratory inflammation processes in coal miners. Half of the subjects were current smokers and half not current smokers (nonsmokers and exsmokers). The subjects were classified as current smokers if they smoked at the time of the study, as non-smokers if they had never smoked, and as exsmokers if they had smoked in the past. Due to the small number of current smokers among retired miners (five in the group without CWP and four in the group with CWP), we decided to compare antioxidants between not current smokers. The examination included a self administered questionnaire (checked by an occupational physician or a nurse) on medical history, medication, dietary habits, and exposure to dust or respiratory irritants, and the questionnaire of the European Community for
Coal and Steel on respiratory symptoms, ${ }^{10}$ and on smoking habits.

To measure the difference of exposure to respirable dust between the two groups of active workers, time weighted average (TWA) dust measurements were performed on all active workers, during the whole shift on three to six consecutive days, at the time of blood sampling, with the individual dust sampler CIP $10 .{ }^{11}$ Chest $x$ ray films, taken after blood sampling, were interpreted according to the International Labour Office (ILO) ${ }^{12}$ international classification of radiographs of pneumoconiosis by three experienced and independent physicians. The films were presented in a random order, without any information about the professional and medical history of the subjects. To increase the consistency of interpretations, the independent reading was preceded by a consensus reading of 15 films, reintroduced in the main reading as trigger films. For the study purposes, subjects with a median profusion of small opacities of $1 / 0$ or more, whatever the shape and size, were considered as presenting a CWP; those with a median profusion of $0 / 1$ or less were considered as not having CWP. This interpretation allowed the verification of inclusion criteria, and eventually reclassification in the different groups.

This study was approved on 23 May 1993 by the Consultative Committee for Human Subjects Protection in Biomedical Research of Metz (Lorraine, France). Written informed consent was collected from each subject.

\section{BLOOD SAMPLES}

Blood samples were collected into $5 \mathrm{ml}$ Vacutainer tubes containing lithium heparinate as an anticoagulant (Becton Dickinson, USA). On the same day, corresponding plasma and haemolysates were prepared as described previously. ${ }^{13}$ Plasma and ghost free haemolysates were stored at $-35^{\circ} \mathrm{C}$

Two hundred microlitres of haemolysate were diluted by addition of $1800 \mu \mathrm{l}$ of $\mathrm{NaCl}$ $(0.9 \%)$. The $\mathrm{Cu}^{++} / \mathrm{Zn}^{++}$SOD was extracted from $0.5 \mathrm{ml}$ of this haemolysate by addition of $0.5 \mathrm{ml}$ of chloroform/ethanol $(15 / 25, \mathrm{v} / \mathrm{v})$. The solution was vortexed and centrifuged at $10500 \mathrm{~g}$ for five minutes. The upper aqueous phase was assayed for $\mathrm{Cu}^{++} / \mathrm{Zn}^{++}$SOD activity.

\section{ENZYMATIC ASSAYS}

Total antioxidants include ascorbate, protein thiols, bilirubin, urate, and $\alpha$ tocopherol. Total antioxidants were measured at $37^{\circ} \mathrm{C}$ in the Cobas-Mira $S$ analyser with a kit based on the method of Miller et al ${ }^{14}$ (Randox Laboratories Crumlin, UK). This method arose from the finding that when 2,2'-azinobis (3-ethylbenzothiazoline-6-sulphonic acid (ABTS)) is incubated with hydrogen peroxide and a peroxidase such as metmyoglobin, the relatively long lived radical cation ABTS ${ }^{+}$is formed. In the presence of antioxidant reductants and hydrogen donors ( $5 \mu \mathrm{l}$ of plasma), the absorbance of this radical cation is quenched to an extent related to the antioxidant capacity of the added fluid. An antioxidant ranking was established based on the reactivity relative to a $1.0 \mathrm{mmol} / \mathrm{l}$ 
Table 1 Age, exposure to respirable coal mine dust $\left(\mathrm{mg} / \mathrm{m}^{3}\right)$, and smoking history of participants in the different groups of coal miners

\begin{tabular}{|c|c|c|c|c|c|c|}
\hline \multirow[b]{2}{*}{ Variables } & \multicolumn{3}{|l|}{ Active workers } & \multicolumn{3}{|l|}{ Retired miners } \\
\hline & $\begin{array}{l}\text { Surface } \\
\text { workers } \\
(n=30)\end{array}$ & $\begin{array}{l}\text { Underground } \\
\text { miners } \\
(n=34)\end{array}$ & $P$ values & $\begin{array}{l}\text { Without } \\
\text { CWP } \\
(n=33)\end{array}$ & $\begin{array}{l}\text { With } \\
C W P \\
(n=21)\end{array}$ & $P$ values \\
\hline \multirow{3}{*}{$\begin{array}{l}\text { Age (mean }(\mathrm{SD}))^{\star} \\
\text { Respirable coal mine dust } \\
\text { exposure (median (range), } \\
\left.\left(\mathrm{mg} / \mathrm{m}^{3}\right)\right)^{\star} \\
\text { Current smoking history } \\
\text { (mean }(\mathrm{SD}), \\
\text { pack-years) }{ }^{\star}\end{array}$} & $37 \cdot 7(2 \cdot 43)$ & $40 \cdot 05(3 \cdot 27)$ & 0.0037 & $59 \cdot 27(2 \cdot 97)$ & $59 \cdot 80(4 \cdot 08)$ & 0.7189 \\
\hline & $0 \cdot 17(0-2 \cdot 87)$ & $1 \cdot 61(0 \cdot 15-21 \cdot 1)$ & 0.0001 & - & - & - \\
\hline & $3(0-41)$ & $8(0-26)$ & $0 \cdot 8007$ & $8(0-84)$ & $5(0-27)$ & $0 \cdot 7821$ \\
\hline $\begin{array}{l}\text { Smokers }(\%) \dagger \\
\text { Non-smokers (\%)† } \\
\text { Exsmokers (\%)† }\end{array}$ & $\begin{array}{l}53 \cdot 3 \\
26 \cdot 7 \\
16 \cdot 7\end{array}$ & $\begin{array}{l}47 \cdot 1 \\
38 \cdot 2 \\
11 \cdot 8\end{array}$ & $0 \cdot 596$ & $\begin{array}{c}0 \\
18 \cdot 2 \\
81 \cdot 8\end{array}$ & $\begin{array}{l}0 \\
38 \cdot 1 \\
61 \cdot 9\end{array}$ & $0 \cdot 104$ \\
\hline
\end{tabular}

${ }^{\star}$ Mann-Whitney $U$ test; $\dagger \chi^{2}$ test.

Trolox standard (the Trolox equivalent antioxidant capacity of plasma). Total antioxidants is defined as the amount of radicals captured non-enzymatically in a litre of plasma. Results were expressed in $\mathrm{mmol} / \mathrm{l}$ (Trolox units, rate (\%)).

The $\mathrm{Cu}^{++} / \mathrm{Zn}^{++}$SOD activity was measured as previously described, ${ }^{13}$ and adapted on a Cobas-Mira $S$ analyser (Hoffman-La Roche, Basel, Switzerland). The concentration of xanthine oxidase in the reaction mixture was 18 $\mathrm{U} / \mathrm{ml}$. The volume sample was $4 \mu \mathrm{l}$ of the upper aqueous phase. Human erythrocyte SOD (Sigma) was used as a standard.

Glutathione peroxidase activity was measured as previously described ${ }^{13}$ in the CobasMira $S$ analyser.

Catalase activity was measured at $25^{\circ} \mathrm{C}$ in a UV 25 Spectrophotometer (Beckman Instruments, France) as previously described. ${ }^{13}$ Catalase activity of $1 \mathrm{k}$ was defined as the constant rate of the first order reaction.

Haemoglobin $(\mathrm{Hb})$ content $(\mathrm{g} / \mathrm{l})$ was measured as previously described. ${ }^{13}$ Activities were expressed as $\mathrm{U} / \mathrm{g} \mathrm{Hb}\left(\mathrm{Cu}^{++} / \mathrm{Zn}^{++} \mathrm{SOD}\right.$, glutathione peroxidase) or $\mathrm{k} / \mathrm{g} \mathrm{Hb}$ (catalase) in erythrocytes, and U/1 (glutathione peroxidase) in plasma.

\section{STATISTICAL METHODS}

The homogeneity $\chi^{2}$ test was performed to compare the proportions of smokers, nonsmokers, and exsmokers between the two groups of active workers and between the two groups of retired miners. All variables presented a normal distribution except the concentration of respirable coal mine dust, the smoking history (pack-years), and the erythrocyte glutathion peroxidase activity in the groups of retired miners. This last variable was $\log$ transformed before statistical analysis and the normality was checked with the ShapiroWilk test. The results were reported as the mean (SD) except for concentration of respirable coal mine dust and smoking history (median (range)) because these variables presented an asymmetric distribution even after $\log$ transformation, as did glutathion peroxidase (geometric mean).

As the sizes of the groups were small, differences between two groups were assessed with the Mann-Whitney $U$ test. As antioxidants may be affected by age and smoking habits, analyses of covariance with age and smoking habits as covariates were performed to compare antioxidants between the groups. For evaluation of the relation between $\mathrm{Cu}^{++} / \mathrm{Zn}^{++}$SOD and respirable coal mine dust concentrations, Spearman's rank correlation $(r)$ was used.

Statistical significance was assessed at the $5 \%$ two sided level. All these analyses were performed with the SAS statistical software (SAS Institute, Cary, North Carolina). ${ }^{15}$

\section{Results}

Table 1 shows the characteristics of the subjects in the different groups. Although active workers between 35 to 45 years old have been selected, surface workers were significantly younger than underground miners. As expected by the recruitment, significant difference in exposure to respirable coal mine dust existed between the group of underground miners and the group of surface workers. No differences were found between active and retired miners on tobacco consumption and proportion of smokers, non-smokers, and exsmokers.

Antioxidants may be affected by potential confounding factors such as age and smoking history. In this study, we found that plasma glutathione peroxidase activity decreased with age in the group of underground miners (data not shown). Moreover, even if there were roughly the same proportions of smokers, nonsmokers, and exsmokers in different groups, the variation within the groups due to the different current smoking histories may obscure the differences between the groups, on the variables of interest. Analyses of covariance, with age and smoking history as covariates, were performed to take into account these confounding factors.

A comparison of the antioxidants between the group of surface workers and the group of underground miners with the Mann-Whitney $U$ test showed several significant differences between the groups (table 2). Erythrocyte $\mathrm{Cu}^{++} / \mathrm{Zn}^{++}$SOD activity was higher in the group of underground miners (even after adjustment for age and smoking history (packyears) in an analysis of covariance). Plasma glutathione peroxidase activity was lower whereas total plasma antioxidants were higher in the group of underground miners but these differences were not significant after adjustment for age (data not shown), or after adjust- 
Table 2 Comparison of antioxidants in active surface workers and underground miners from Lorraine

\begin{tabular}{|c|c|c|c|c|c|c|}
\hline \multirow[b]{2}{*}{ Variables } & \multicolumn{3}{|l|}{ Unadjusted values } & \multicolumn{3}{|c|}{ Values adjusted for age ${ }^{*}$} \\
\hline & $\begin{array}{l}\text { Surface } \\
\text { workers } \\
(n=30)\end{array}$ & $\begin{array}{l}\text { Underground } \\
\text { miners } \\
(n=34)\end{array}$ & $\begin{array}{l}\text { Mann-Whitney } \\
\text { U test } \\
P \text { values }\end{array}$ & $\begin{array}{l}\text { Surface } \\
\text { workers } \\
(n=30)\end{array}$ & $\begin{array}{l}\text { Underground } \\
\text { miners } \\
(n=34)\end{array}$ & $\begin{array}{l}\text { Analyse of } \\
\text { covariance } \\
P \text { values }\end{array}$ \\
\hline \multirow{3}{*}{$\begin{array}{l}\text { In erythrocytes: } \\
\text { Catalase }(\mathrm{k} / \mathrm{g} \mathrm{Hb}) \\
\text { Glutathione peroxidase } \\
(\mathrm{U} / \mathrm{g} \mathrm{Hb}) \\
\mathrm{Cu}^{++} / \mathrm{Zn}^{++} \text {SOD }(\mathrm{U} / \mathrm{g} \mathrm{Hb}) \\
\text { In plasma: }\end{array}$} & $135 \cdot 51(28 \cdot 15)$ & $142 \cdot 78(33 \cdot 32)$ & 0.4634 & $134.93(5.95)$ & $143 \cdot 29(5 \cdot 56)$ & 0.3995 \\
\hline & \multirow[t]{2}{*}{$\begin{array}{r}34.57(13.77) \\
156.99(37.54)\end{array}$} & \multirow[t]{2}{*}{$\begin{array}{r}34.47(11 \cdot 67) \\
182 \cdot 22(31.92)\end{array}$} & $\begin{array}{l}0.9196 \\
0.0008\end{array}$ & \multirow[t]{2}{*}{$\begin{array}{r}34 \cdot 30(2 \cdot 43) \\
157 \cdot 00(6 \cdot 66)\end{array}$} & $\begin{array}{r}34 \cdot 71(2 \cdot 27) \\
182 \cdot 21(6 \cdot 22)\end{array}$ & $\begin{array}{l}0 \cdot 6341 \\
0 \cdot 0131\end{array}$ \\
\hline & & & & & \multirow[b]{2}{*}{$\begin{array}{l}439.58(16.84) \\
1.32(0.02)\end{array}$} & \\
\hline $\begin{array}{l}\text { Glutathione peroxidase }(\mathrm{U} / \mathrm{l}) \\
\text { Total antioxidants }(\mathrm{mmol} / \mathrm{l})\end{array}$ & $\begin{array}{l}478 \cdot 31(89 \cdot 08) \\
1.26(0 \cdot 13)\end{array}$ & $\begin{array}{c}425 \cdot 20(110.67) \\
1.32(0 \cdot 11)\end{array}$ & $\begin{array}{l}0.0422 \\
0.0133\end{array}$ & $\begin{array}{l}462.02(18.01) \\
1.27(0.02)\end{array}$ & & $\begin{array}{l}0 \cdot 3427 \\
0 \cdot 1867\end{array}$ \\
\hline \multicolumn{7}{|c|}{$\begin{array}{l}\text { Results are expressed as mean (SD). } \\
\star \text { Least squares means: means were adjusted for age with the GLM procedure; †Age and smoking history (pack-years) were the } \\
\text { covariates. }\end{array}$} \\
\hline \multicolumn{7}{|c|}{ Table 3 Comparison of antioxidants in retired miners with and without CWP } \\
\hline Variables & \multicolumn{2}{|c|}{$\begin{array}{l}\text { Without } \\
C W P \\
(n=33)\end{array}$} & $\begin{array}{l}\text { With } \\
C W P \\
(n=21)\end{array}$ & $\begin{array}{l}\text { Mann-Whitne } \\
U \text { test } \\
P \text { values }\end{array}$ & \multicolumn{2}{|c|}{$\begin{array}{l}\text { Analyse of } \\
\text { covariance } \\
P \text { values }\end{array}$} \\
\hline $\begin{array}{l}\text { In erythrocytes: } \\
\text { Catalase }(\mathrm{k} / \mathrm{g} \mathrm{Hb}) \\
\text { Glutathione peroxidase }\end{array}$ & \multicolumn{6}{|c|}{ In erythrocytes: } \\
\hline $\begin{array}{l}\text { (U/g Hb) } \\
\mathrm{Cu}^{++} / \mathrm{Zn}^{++}\end{array}$ & \multicolumn{2}{|c|}{$\begin{array}{c}30.87(1.52) \\
161.94(36.99)\end{array}$} & $\begin{array}{l}29 \cdot 37(1 \cdot 61) \\
162 \cdot 13(33 \cdot 05)\end{array}$ & $\begin{array}{l}0 \cdot 7629 \\
0 \cdot 7629\end{array}$ & \multicolumn{2}{|l|}{$\begin{array}{l}0 \cdot 8545 \\
0 \cdot 9687\end{array}$} \\
\hline \multicolumn{7}{|l|}{ In plasma: } \\
\hline $\begin{array}{l}\text { Glutathione peroxidase }(\mathrm{U} / \mathrm{l}) \\
\text { Total antioxidants }(\mathrm{mmol} / \mathrm{l})\end{array}$ & \multicolumn{2}{|c|}{$\begin{array}{c}479 \cdot 27(140 \cdot 26) \\
1 \cdot 18(0 \cdot 12)\end{array}$} & $\begin{array}{c}571 \cdot 09(133 \cdot 55) \\
1 \cdot 15(0 \cdot 10)\end{array}$ & $\begin{array}{l}0.0091 \\
0.2788\end{array}$ & \multicolumn{2}{|l|}{$\begin{array}{l}0.0397 \\
0.3450\end{array}$} \\
\hline
\end{tabular}

Results are expressed as mean (SD) except for erythrocyte glutathione peroxidase (geometric mean).

${ }^{\star}$ Age was the only covariate.

ment for age and smoking history. Erythrocyte catalase and glutathione peroxidase activities in the group of underground miners did not differ from those measured in the group of surface workers. There was no significant correlation between erythrocyte $\mathrm{Cu}^{++} / \mathrm{Zn}^{++}$SOD activities and concentrations of respirable coal mine dust (data not shown)

A comparison of the antioxidants between the groups of retired miners with and without pneumoconiosis with the Mann-Whitney $U$ test showed that plasma glutathione peroxidase activity was higher in the group of retired miners with pneumoconiosis (table 3). The difference remained significant in an analysis of covariance with age as the only covariate. Erythrocyte enzyme activities and total plasma antioxidants in the group of retired miners with pneumoconiosis were not different from those measured in the group of retired miners without pneumoconiosis (even after adjustment for age).

\section{Discussion}

This study was started to find out if blood and plasma antioxidants $\left(\mathrm{Cu}^{++} / \mathrm{Zn}^{++}\right.$SOD, glutathione peroxidase, catalase, and total plasma antioxidants) could be markers of either biological activity resulting from exposure to respirable coal mine dust in active miners, or of pneumoconiosis in retired miners.

Erythrocyte $\mathrm{Cu}^{++} / \mathrm{Zn}^{++} \mathrm{SOD}$ activity was significantly higher in underground miners exposed to respirable dust particles than in surface workers. To our knowledge, this difference has never been previously reported in epidemiological studies. Our result is in accordance with animal studies by Janssen et $a l^{6}$ who showed that inhalation of particles that caused pulmonary inflammation and fibrosis also caused dramatic increases after eight weeks in MnSOD mRNA concentrations in rat lung that correlated with increases in MnSOD immunoreactive protein. These results show that exposure to fibrogenic mineral dusts causes an increase in specific antioxidant enzymes, most notably MnSOD and the authors suggest MnSOD as a potential marker of inflammatory reaction caused by exposure to mineral dust. They found no significant changes in expression of $\mathrm{Cu}^{++} / \mathrm{Zn}^{++} \mathrm{SOD}$ mRNA or in $\mathrm{Cu}^{++} / \mathrm{Zn}^{++} \mathrm{SOD}$ protein concentrations in rat lung but this discrepancy is probably due to the use of different biological samples and a different assay. Our results suggest that erythrocyte $\mathrm{Cu}^{++} / \mathrm{Zn}^{++} \mathrm{SOD}$ activity may also be considered as a marker of effect in miners exposed to respirable coal mine dust and may be predictive of the inflammation and pneumoconiosis induced by coal mine dust. Future studies should consider the question of a dose response.

After adjustment for age and smoking history, we found no significant differences in total plasma antioxidants between the group of surface workers and the group of underground miners. Even if the measurement of total plasma antioxidants is marginally less rigorous than "total radical-trapping antioxidant parameter" (TRAP) ${ }^{14}$ our result is in accordance with that of Schins et al ${ }^{16}$ who have measured the TRAP in serum samples of coal workers. They did not find any significant difference in TRAP concentrations between controls not exposed to dust, control miners, and miners with CWP. The differences in total plasma antioxidants and plasma glutathione peroxidase activity between the group of underground miners and the group of surface workers may be related to age. This result is in accordance with published data ${ }^{131^{17-18}}$ and is in agreement with the hypothesis of the free radical theory of aging. ${ }^{19} \mathrm{We}$ found no available publications on the effect of age on total plasma antioxidants. Nevertheless, even if ascorbate, 
protein thiols, bilirubin, urate, and $\alpha$ tocopherol account for $90 \%$ of the total plasma antioxidant activity, the remaining $10 \%$ is accounted for by substances such as glutathione and glutathione has the same molar equivalent antioxidant capacity as Trolox. ${ }^{16} \mathrm{An}$ interesting issue is that variations in glutathione may be a factor causing the difference in plasma glutathione peroxidase activity.

We found that glutathione peroxidase activity was higher in plasma of retired miners with pneumoconiosis, than in retired miners without pneumoconiosis, even after adjustment for age. These findings are in agreement with other studies. Engelen et al and Borm et al reported an increase in total red blood cell glutathione peroxidase activity in the early stages of CWP (miners with classification $0 / 1$ to $1 / 2) .^{20-23}$ We suggest that enhancement of glutathione peroxidase activity in plasma of retired miners with pneumoconiosis is due to disease activity. Rom $e t a^{24}$ found that alveolar macrophages from non-smoking people with CWP were spontaneously releasing increased amounts of $\mathrm{H}_{2} \mathrm{O}_{2}$. Dallal et $\mathrm{al}^{25}$ found that the free radical content of the lung tissues of necropsied coal miners correlated with the severity of pneumoconiosis; the more severe the disease, the higher the radical concentration in the lung tissue. The increase in glutathione peroxidase activity in the plasma of retired miners with pneumoconiosis could be the result of a response to the increasing $\mathrm{H}_{2} \mathrm{O}_{2}$ production by alveolar macrophages and neutrophils.

A previous report ${ }^{1}$ showed that alveolar inflammatory cells from bronchoalveolar lavage of patients with CWP release more $\mathrm{O}_{2}{ }^{-}$ and have slightly but not significantly more SOD activity than do those from healthy control subjects. Engelen $e t a l^{20}$ found no significant differences in SOD activity between healthy miners and three subgroups of miners with CWP. In our study, we did not find any difference in $\mathrm{Cu}^{++} / \mathrm{Zn}^{++}$SOD activity between retired miners without pneumoconiosis and retired miners with pneumoconiosis. The discrepancy with the report of Wallaert et $a l^{1}$ is probably due to the use of different biological samples and enzymatic assay.

In conclusion, the changes in blood antioxidants that we have measured are in agreement with the hypotheses that production of reactive oxygen species is an important event in the exposure to coal mine dust particules and in pneumoconiotic activity. In spite of our small samples, our findings indicate that erythrocyte $\mathrm{Cu}^{++} / \mathrm{Zn}^{++}$superoxide dismutase activity may be considered as a marker of the effect of respirable coal mine dust in exposed workers, and plasma glutathione peroxidase activity may be considered as a biological marker of pneumoconiosis in coal miners. We acknowledge the contribution of $\mathrm{Dr} M$ Guenzi, Dr P
Heintz, and Dr M Zitter (Houillères du Bassin de Lorraine), Dr Heintz, and Dr M Zitter (Houilleres du Bassin de Lorraine), Dr P Cervantes (Occupational lung disease centre of St Avold) and biological samples. We also thank Mrs Urschel and her technicians for preparing and aliquoting plasma and washed erythrocytes (Laboratory of Hospitalor, St Avold). We are grateful to cytes (Laboratory of Hospitalor, St Avold). We are grateful to Professor S Briançon for helpful comments, and to Anne Bar for revising the manuscript. This study was supported by the
fifth Programme of Medical Research of the European fifth Programme of Medical

1 Wallaert B, Lasalle P, Fortin F, Aerts C, Bart F, Fournie E, Voisin C. Superoxide anion generation by alveola inflammatory cells in simple pneumoconiosis and in progressive massive fibrosis of no smoking coal workers. $A m$ Rev Respir Dis 1990;141:129-33.

2 Malech HL, Gallin JI. Neutrophils in human diseases. $N$ Engl f Med 1987;317:687-94.

3 Root RK, Metcalf JA. $\mathrm{H}_{2} \mathrm{O}_{2}$ release from human granulocytes during phagocytosis. Relationship to superoxide anion formation and cellular catabolism of $\mathrm{H}_{2} \mathrm{O}_{2}$ : studies with normal and cytochalasin $\beta$-treated cells. $\mathscr{f}$ Clin Invest with normal and cyto

4 Petit JC, Boettner JC. Evidence of $\mathrm{H}_{2} \mathrm{O}_{2}$. Formation in the early stage of coal oxidation. In: Charcosset $\mathrm{H}$, ed. Advanced methodologies in coal characterisation. Amsterdam: Elsevier, 1990:253-66.

5 Berg I, Schlüter T, Gercken G. Increase of bovine alveola macrophage superoxide anion and hydrogen peroxide release by dusts of different origin. $\mathcal{F}$ Toxicol Environ Health 1993;39:341-54.

6 Janssen YMW, Marsh JP, Driscoll KE, Borm PJA, Oberdörster G, Mossman B. Increased expression of manganese-containing superoxide dimutase in rat lungs after inhalation of inflammatory and fibrogenic minerals. Free Rad Biol Med 1994;16:315-22.

7 Pryor WA. Oxy-radicals and related species: their formation, lifetimes, and reactions. Annu Rev Physiol 1986;48. 657-67.

8 Schulte PA. A conceptual framework for the validation and use of biologic markers. Environ Res 1989;48:129-44.

9 Quanjer PH, Tammeling GJ, Cotes JE, Pedersen OF, Peslin $\mathrm{R}$, Yernault JC. Lung volumes and forced ventilatory flows. Eur Respir f 1993;6:5-40.

10 Minette A. Questionnaire of the European Community for Coal and Steel (ECCS) on respiratory symptoms. Eur Respir f 1989;2:165-77.

11 Courbon P, Vorebel R, Fabries JF. A new individual respirable dust sampler: the CIP 10. Ann Occup Hyg 1988; 32:129-43.

12 Guidelines for the use of ILO international classification of radiograms of pneumoconiosis. Geneva: International Labour ograms of pneumoconiosis. Geneva: International Labour 22.)

13 Perrin R, Briançon S, Jeandel C, Artur Y, Minn A, Pennin F, Siest $\mathrm{G}$. Blood activity of $\mathrm{Cu} / \mathrm{Zn}$ superoxide dismutase, glutathione peroxidase and catalase in Alzheimer's disease: a case-control study. Gerontology 1990;36:306-13.

14 Miller NJ, Rice-Evans C, Davies MJ, Gopinathan V, Milner A. A novel method for measuring antioxidant capacity and its application to monitoring the antioxidant status in premature neonates. Clin $S c i$ 1993;84:407-12.

15 SAS Institute. SAS/stat user's guide, version 6, 4th ed. Cary, NC: SAS Institute, 1990.

16 Schins RPF, Derhaag TJM, De Jong J, Bast A, Borm PJA. Serum total radical-trapping antioxidant parameter

17 Guemouri L, Artur Y, Herbeth B, Jeandel C, Cuny G, Siest $\mathrm{G}$. Biological variability of superoxide dismutase, glutathione peroxidase and catalase in blood. Clin Chem 1991;37:1932-7.

18 Schäfer L, Thorling EB. Lipid peroxidation and antioxidant supplementation in old age. Scand $\mathcal{f}$ Clin Lab Invest 1990;50:69-75.

19 Harman D. Free radicals in aging. Mol Cell Biochem 1988;84:155-61.

20 Engelen JJM, Borm PJA, Van Sprundel M, Leenaerts L. Blood anti-oxidant parameters at different stages of pneumoconiosis in coal workers. Environ Health Perspect 1990;84:165-72.

21 Borm P, Palmen N, Engelen J, Buurman WA. In: Mossman BT, Beguin RO, eds. Effects of mineral dusts on cells. Berlin: BT, Beguin RO, eds. Effects of

22 Borm PJA, Engelen JJM, Palmen N, Buurman WA. Red blood cell anti-oxidants and monocyte tumor necrosis facblood cell anti-oxidants and monocyte tumor necrosis fac-
tor (TNF). In: Sebastien P, ed. The pathogenesis of coal tor (TNF). In: Sebastien P, ed. The pathogenesis of coal
workers' pneumoconiosis. Mechanisms in occupational lung diseases. Vandoeuvre-les-Nancy Cedex, France: Colloque INSERM 1991;203:161-7.

23 Borm PJA, Meijers JMM, Swaen GMH. Molecular epidemiology of coal worker's pneumoconiosis: application to risk assessment of oxidant and monokine generation by mineral dusts. Exp Lung Res 1990;16:57-71.

24 Rom WN, Bitterman PB, Rennard SI, Cantin A, Crystal RG. Characterization of the lower respiratory tract inflammation of nonsmoking individuals with interstitial lung disease associated with chronic inhalation of inorganic dusts. Am Rev Respir Dis 1987;136:1429-34.

25 Dalal NS, Suryan MM, Vallyathan V, Green FHY, Jafari B, Wheeler $R$. Detection of reactive free radicals in fresh coal mine dust and their implication for pulmonary injury. Ann Occup Hyg 1989;33:79-84. 